\title{
Discourse Roles of Particles in Chiyao'
}

\author{
Julius Taji² \\ University of Dar es Salaam
}

\begin{abstract}
This paper seeks to investigate the discourse roles of particles in Chiyao along with their environment of occurrence and scope of interpretation. The analysis is based on the data collected through audio-recording of traditional narratives which were later transcribed to identify utterances with particles. The findings establish that particles in Chiyao can occur in three major types of environment, namely within the NP as is the case with question particles, demonstrative particles, and exclusive particles; within the VP as is the case with question particles, exclusive particles, and negative particles; and in pre-sentential position (e.g. emotional particles, additive particles, and contrast particles). Concerning the scope of interpretation, the analysis indicates that particles that occur within the NP have their scope of interpretation limited to the NP, while the meaning of those that occur as part of the VP or in pre-sentential position applies to the entire sentence. As for the discourse roles, it is shown that the Chiyao particle performs different significant roles, including emphatic roles, such as emphasising negation; and exclusive roles, that is, to single out some elements within a clause from the rest of a clause in order to show focus. It is further shown that particles are used to signal interrogation, and for anaphoric purposes. Moreover, particles in Chiyao indicate deixis as well as emotions such as surprise, anger, disapproval and shock. Finally, particles indicate contrast and addition. These findings lead to a conclusion that the use of particles represents an important communicative strategy in Chiyao.
\end{abstract}

Keywords: Bantu, Chiyao, Particle, Discourse, Role

\section{Introduction}

The existence of particles in language has been acknowledged in quite a number of crosslinguistic and language specific studies although with some opposing views as to whether they are words, clitics, affixes (Zwicky, 1985) or simply holophrases (Christidis, 1990). Regardless of their categorization (whether they are words or not) it is generally acknowledged that particles are multifunctional and heterogeneous, encompassing various categories of word functions such as conjunctions, adverbs, interjections, and prepositions and they perform interactional, referential, and structural functions (Tzartzanos, 1991).

${ }^{1}$ This study/project was made possible by the Partnership for Africa's Next Generation of Academics (PANGeA) Early Career Fellowship progamme, which is funded by the Robert Bosch Stiftung.

${ }^{2}$ Dr. Julius Taji is a lecturer in the Department of Foreign Languages and Linguistics, University of Dar es Salaam, Tanzania. He holds a PhD (Linguistics), an M.A. (Linguistics), and a B.A. (Education) all of which obtained at the University of Dar es Salaam. His areas of specialization include morphosyntax of Bantu languages, lexicography and Sign Language. Dr. Taji is currently attending a one year full time postdoctoral fellowship hosted by the Department of Linguistics and Language Practice at the University of the Free State (UFS), South Africa. Email: juliustaji@gmail.com 
Particles may occur as either bound morphemes or free morphemes, and their interpretation may either be limited to the elements that they are affixed to or to the entire clause. The Swahili interrogative particle je provides a good example of this multiple occurrence and role of particles. Nicolle (2000) observes that the Swahili interrogative particle je occurs both as a bound morpheme and as a free morpheme. When it occurs as a bound morpheme, it is attached to verbs giving a pragmatic interpretation as a wh-question (how) (1a) and when it occurs as a free morpheme its scope stretches to the entire clause giving the interpretation of a yes/no question (1b).
(1) a. M-dudu a-me-ingia-je?
1-insect 1SM-PERF-enter-PART
'How did the insect enter?'
b. Je! Huu ni uungwana?
PART this is right

'Is this right?'

(Swahili, Nicolle, 2000)

Within their scope, particles have been associated with various grammatical and communicative roles in different languages of the world. For example, in Modern Greek, the particles na, $\theta a$ and in are used to indicate modality (Roussou \& Tsangalidis, 2010). Moreover, in Awing, a Grassfields Bantu language, the particle lə marks exhaustive focus while the particles tsoə 'only' and kə 'also' mark exclusiveness (Fominyam \& Simık, 2017). In Kinande, the particle na/naye 'also/too' indicates addition (Schneider-Zioga, 2015). Additionally, in other languages, such as Kikisi, Kindendeule and Chingoni particles function to indicate negation (Ngonyani, 2003). Although some of these examples are not from Bantu languages (e.g. Greek), they are important in the analysis of a Bantu language since they seem to perform similar functions.

Given these roles, it is evident that particles are important grammatical and communicative elements in language. As such, further investigation into their linguistic behaviours and roles is called for. This paper offers an investigation of particles in Chiyao, a Bantu language of southern Tanzania $^{3}$, with the purpose of accounting for their environment of occurrence, scope of interpretation, and communicative role. The analysis is based on coherence approach as presented in Schiffrin (1987) who built on the ideas of Halliday and Hasan (1976). The approach focuses on the role of discourse markers (which in the present work are referred to as particles) in coherence, looking into "how speakers and hearers jointly integrate forms, meanings and actions to make overall sense out of what is said" (Schiffrin, 1987, p. 49). In this approach, particles are viewed as verbal devices that function to establish connections between discourse units and parts of their context, encompassing items from different word classes, such as conjunctions and adverbs (Bonifazi et al., 2016). They are also viewed as signals of structural organization of a discourse and indicators of some aspects of language use (Maschler, 1998 as cited in Bonifazi et al., 2016). This approach is relevant to the current discussion of particles in Chiyao as it provides a framework for accounting for their contexts of occurrence and meaning. In this paper, the focus is on the environment of occurrence, scope of interpretation, and communicative role of particles in Chiyao.

\footnotetext{
3In Guthrie's (1948) classification of Bantu languages, Chiyao is classified as P.21 and is also spoken in Mozambique and Malawi.
} 
The paper proceeds by providing some terminological accounts, and then it presents the communicative roles of particles and their contexts of occurrence. Finally, it offers a conclusion and summary.

\section{Terminological accounts}

Particles exist in every language but there are variations in their labelling and treatment among scholars. As such, they have been referred to by different terms by different scholars. Kusevska (2019) uses the term pragmatic markers and defines them as expressions that speakers use to achieve a smooth flow of speech and help their interlocutors decode the meaning of their utterances appropriately. He includes examples of English utterances such as yeah, right, well, I mean, like, and you know. Similarly, Beeching (2016) used the term pragmatic markers, placing more emphasis on their sociolinguistic and interactional quality. On the other hand, Crible (2018), and Schiffrin (1987) use the term discourse markers to refer to the same. Other common terms in the literature include discourse particles, pragmatic particles, pragmatic expressions, and connectives (Kusevska, 2019). However, despite these terminological differences, it is generally agreed that particles or pragmatic markers facilitate spontaneous speech production and interaction and prevent the speaker from being seen as impolite or awkward (Crystal, 1998; Muller, 2005; Kusevska, 2019). Particles in Chiyao, as it will be established in the subsequent sections, seem to reflect this general observation. The following section discusses different discourse roles of particles and their environment of occurrence in Chiyao.

\section{Discourse roles of particles and their context of occurrence}

As pointed out in the preceding section, the literature indicates that particles serve different grammatical and communicative purposes across languages. It is these grammatical and communicative roles that warrant further investigation in languages in which particles have not been thoroughly described. The following sections explore different communicative purposes that particles serve in Chiyao. The analysis of the roles also takes into account their environment of occurrence and scope of interpretation.

\section{Interrogation}

Interrogative constructions in Chiyao are indicated prosodically by raising intonation, leaving the word order in situ. In addition to the raising intonation, a new element, an interrogative particle, may be introduced to the beginning of a construction or may be inserted in the interrogative construction. There are three elements in Chiyao which frequently occur as interrogative particles, namely ana, ngati and ambano. Below are extracts from traditional narratives illustrating the context of use of these particles. Each extract is followed by a free translation in English.

Aná a-mbusánga mmwé ngáti m-kúwóná sálâ?

PART 1a-friend you PART 1SM-feel 9.hunger

'Hey my friend, do you see that you are starving?'
Akulu vao ni va-janga-aga,
'ambáno
tu-tende
uli?'
Elder his then 2SM-answer-PST PART

'Their elders then asked, 'so what should we do?'

The sentences above demonstrate three communicative roles performed by the three interrogative particles in Chiyao. They indicate that although the particles are generally used for interrogation, each of them has a specific communicative context and effect. Example (2) contains two particles: ana and ngati. In this utterance, the speaker uses the particle ana at the beginning of a clause to get the addressee's attention to the question he/she is about to pose. In this case, it roughly translates to the English interjection hey which is used in similar contexts in English. It 
is therefore convincing to establish that the particle ana functions to get the addressee pay attention to the question being asked by the speaker. As for the particle ngati, it precedes the verb in example (2). The speaker uses it to introduce a question but with two additional conditions: the question triggers a yes/no answer, and that answer is obvious; it is therefore a rhetorical question. The particle ngati is therefore used to introduce questions in contexts where both the speaker and the addressee have enough clues about the answer. Unlike the interrogative particle ngati which triggers a yes/no answer, the particle ambano, which is exemplified in (3) above, is used in open questions, particularly, opinion seeking questions. In example (3), the speaker uses it to introduce a question whose answer requires an explanation to solve the existing problem. Therefore, although the particles ana, ngati and ambano are all used in question contexts, the communicative purposes for which speakers use them are not the same.

\section{Exclusion}

Particles which mark exclusion in Chiyao occur with different word categories to single them out from other members in a clause. The exclusion of an entity out of an utterance may be motivated by an expression of focus. Thus, the singled out entity is what the speaker focuses on. Two exclusive particles have been established from the data, namely $p e$ and $t u$. These are illustrated in (4) below before giving an account of their communicative effects.
a. chi-lambó chi chi-sigale ní va-náche 7-world this 7OM-remain with 2-child
'This village should remain with children only.'
b. ku-sigála va-chanda tú.
INF-remain 2-boy PART
'Only children remained'
(c) li-jóká lila li-kopwésye m-twé tú.

5-snake that 3SM-expose 3-head PART
'That snake exposed only its head.'
(d) m-ka-li-távé tú
1SM-FUT-5OM-tie PART
'Just go and tie it.'

pe.

PART

From the preceding extracts, it seems that each of the two particles pe and $t u$ has a different environment of occurrence and has a distinct communicative effect. In terms of occurrence, the particle pe, qualifies nouns only as is the case in (4a) where it occurs after a noun vanáche 'children'. On the other hand, the particle tú qualifies both nouns (e.g. vachanda 'boys' in (4b) and mtwé 'head' in (4c)), and verbs (e.g. mkalitávé 'go and tie it' in (4d)). As for communicative effects, the two particles take different interpretations depending on the word class that they occur with. Thus, the particles pe and tu occurring with nouns have an adjectival reading 'only' with semantic scopes limited to the NPs in which they occur. On the other hand, the particle tu occurring with a verb has an adverbial reading 'just' and its semantic scope stretches to the entire sentence since the verb is the core unit of a sentence. It follows therefore that the particle tu carries different semantic interpretations depending on whether it modifies a noun or a verb. Apparently, the particle pe cannot be used to qualify verbs. Thus, when the exclusion particle tu in (4d) is replaced with pe the utterance becomes ungrammatical as in (5) below.

$$
\begin{array}{ll}
\text { *m-ka-li-távé } & \text { pe } \\
\text { 1SM-FUT-5OM-tie } & \text { PART }
\end{array}
$$


Intended: 'Just go and tie it.'

Since exclusive particles change their semantic scope depending on the type of word they qualify as pointed out above, they have been regarded as one of the resources for focus marking in some languages. Thus, a speaker would place an exclusive particle near the element that he/she intends to assign more weight than others. In Makhuwa and Zulu, for example, focus is indicated by exclusive particles paáhi 'only' and kuphela 'only' respectively (van der Wal, 2014:6-7), as illustrated in the following examples.
a. O-lomw-e
1.SM-see-PERF.CJ
ehopa
paáhi
'He caught only fish.'
10.fish only
(Makhuwa, van der Wal, 2014:7)
b. Ngi-bon-e 1SG.SM-see-PERF.CJ
'I saw only Sipho.'
uSipho kuphela.
1.Sipho only
(Zulu, van der Wal, 2014:6)

In the Makhuwa example (6a) above, the exclusive particle paáhi 'only' has been used to indicate the speaker's focus on ehopa 'fish' to mean nothing else other than fish was bought. Similarly, the Zulu particle kuphela 'only' in (6b) places focus on seeing the person Sipho and not any other person, thus marking exclusive focus.

\section{Negation role}

The canonical marker for negation in Chiyao is the morpheme nga- which is inserted in the verb initial position before the subject marker, as in the examples in (7) below where (7a) is an affirmative statement and (7b) is a negative statement.
(7) a. a-ku-teleka nsele
1SM-PRES-cook 9.rice
'He/she is cooking rice.'
b. nga-a-ku-teleka nsele
NEG-1SM-PRES-cook 9.rice
'He/she is not cooking rice.'

In addition to the use of the negative marker nga-, negation in Chiyao can further be achieved by adding the negation particle ngu to the end of a clause as in (8) below.

(8) a. nga-ngw-aula

NEG-1SG.PRES-go

'I am not going.'
b. nga-ngw-aula ngu!
NEG-1SG.PRES-go PART
'I am not going (at all)'

The negative construction in (8a) appears without a negative particle while its counterpart in (8b) contains a particle $n g u$. Although both sentences have a negative reading, the negative sentence in (8b) is understood to be more emphatic than (8a) due to the addition of a negative particle $n g u$ which yields an extra interpretation 'at all.' Therefore, communicatively, the negative particle adds emphasis to the negative sense of a construction, implying that the speaker is more categorical in what he/she is saying. 
The double marking of negation illustrated above seems to evidence Devos and Van der Auwera's (2013:205) claim regarding the behaviour of negative markers in Bantu. They asserted that in some Bantu languages, negative markers take part in what is generally known as a Jespersen cycle whereby they initially reinforce the original negator and eventually become obligatory for the expression of negation resulting in a double negative construction. Apparently, the Chiyao negative particle $n g u$ in (8b) above is at the initial stage of the Jespersen cycle as it reinforces the original negator, and may later develop into a full negator.

It is interesting to note that while the negation particle in Chiyao is optional, in several other Bantu languages in southern Tanzania, such as Kikisi, Kindendeule and Chingoni, the negative particle is an obligatory element for encoding negation and the absence of which makes the sentence affirmative. In Chingoni, for example, Ngonyani (2013) observes that the negative particle lepa is used to indicate sentential negation, as shown below:

(9) a. m-geni a-tol-ili u-gimbi

1-guest 1SM-take-PF 14-beer

'The guest took beer.'

b. m-geni a-tol-i lepa u-gimbi

1-guest 1SM-PT-take-PF NEG 14-beer

'The guest did not take beer.' $\quad$ (Chingoni, Ngonyani, 2013:178)

A similar scenario holds in Kindendeule where the negative particle jee or jeka obligatorily appears after the verb to express negation, as shown in the examples below:
(10) a ךeni
a-ki-tol-a
u-gembe
1-guest 1SM-PT-take-IND 14-beer
'The guest took the beer.1
b. $\quad$ ni a-ki-tol-a je u-yembe
1-guest 1SM-PT-take-IND NEG 14-beer

'The guest did not take the beer. (Kindendeule, Ngonyani, 2013:177-178)

The examples in (9) and (10) suggest that while in Chingoni and Kindendeule the negative particle marks negation and therefore it is obligatory in negative constructions, in Chiyao the particle emphasizes negation and therefore it is optional.

\section{Anaphoric role}

Another use of particles in Chiyao is to indicate anaphoric reference. In anaphoric reference, a linguistic element is used to refer to an entity which has been mentioned earlier in the discourse (Lyons, 1999). Particles serving an anaphoric role are used to refer to an entity with which the hearer is familiar not from the physical situation but from the linguistic context. The hearer is familiar with the entity because of its earlier mention in the text or discourse. The anaphoric role of particles in Chiyao is performed by locative particles, which are shortened or cliticised forms of locative nouns. Locative particles occur after locative nouns to co-reference such nouns. They correspond with locative noun classes 16 (pa-), 17 (ku-), and 18 (mu-). Just like locative nouns, they are found in three deictic dimensions, namely proximal, non-proximal and distal. Table 1 below presents the Chiyao locative particles serving anaphoric role and their deictic dimensions. 
Table 1

Locative particles and their deictic dimensions

\begin{tabular}{|l|l|l|l|}
\hline Class & \multicolumn{3}{|c|}{ Particle } \\
\hline & Proximal & Non-proximal & Distal \\
\hline 16 & pa & po & pala \\
\hline 17 & ku & ko & kula \\
\hline 18 & mu & mo & mula \\
\hline
\end{tabular}

The extracts in (10) below provide contextual examples of some of the locative particles found in Table 1.

(11) a. 1 Ché-liitúnu apángené uganja ní ché-sungúla.

A hyena and a hare were friends.

2 Vatemí temíí, vanyamá achínjáo ni vavávílasisyé likwáta.

After sometime, their fellow animals organized a traditional dance.

3 Nambó lyélila likwáta lila váátité vaangáli mavéngwa akaika, pé palikwáta po, mpaká ave ní mávéngwa.

But they said animals that do not have horns will not be allowed to go there, they must have horns.

4 Ché-litúnu na ambusánga vao ché-sungúla ní váátite ambáno ambusánga pélépa

5 chitújile úli pakwaúla kwé kulikwáta kula?

The hyena and his friend the hare thought, 'so my friend how can we go there?

6 Basí ambusánga tujaule kwíikonde tukausóse mpiíngó, nné chíisipe mávéngwa.

$7 \quad$ Kwé kulikwáta ko tutújaule

My friend, let us go to the forest to find an ebony tree, and I will make horns. We will go there.

b. 1 Kiongósi jula atèémi ní uongósi wakwe, siku mója vagónile lugono Iwá músi

2 pannango, ajaséme, ní lyáiché lijóká kwinjíla nkwang’wa múla.

The leader stayed in power for some time, one day when he was having a siesta at his door, a snake came and entered there.

In extract (11a) above, three locative particles are evident, namely po (line 3), kula (line 5), and ko (line 7). They all occur immediately after their respective locative nouns, which are palikwáta 'at the traditional dance' (line 3), and kulikwáta 'to the traditional dance' (lines 5 and 7). Moreover, in extract (10b), one locative particle can be observed, the particle múla which co-references the locative noun nkwang'wa' in the mouth' (line 2). Occasionally, the locative particle occurs twice (before and after a locative noun) to co-reference the same locative noun but in two different forms. This is evident in (11a) pé palikwáta po (line 3), kwé kulikwáta kula (line 5), and kwé kulikwáta ko (line 7). The form that occurs first includes the locative prefix in its appropriate deictic dimension while the form which occurs last includes the locative suffix. Thus, pé (line 3 ) is shortened from pelepo while kwé (lines 5 and 7) is shortened from kwékula.

All the locative particles in the above contexts function anaphorically to maintain the addressee's attention on the subject which has been earlier introduced in the text/discourse. In text (11a), the main subject is likwata 'traditional dance'. This has been introduced in the second line of the text without a locative particle. After the first mention, all the subsequent references to it accompany the locative particle since the addressee is already aware of the existence of this entity or event as seen in line 3 pé palikwáta po, line 5 kwé kulikwáta kula, and line 7 kwé kulikwáta ko. Similarly, in text (11b), the locative particle múla is used for anaphoric reference purposes. 
Although the locative noun that it co-references, nkwang'wa' in the mouth', has not been overtly introduced earlier, its earlier mention is implied by the verb ajaséme ${ }^{4}$ 'he/she has opened his/her mouth' whose meaning implies that one has a mouth.

\section{Deictic role}

One of the important roles of particles in Chiyao is to indicate deixis. According to Lyons (1999, p. 18), "deixis is the property of certain expressions or categories of relating things talked about to the spatial temporal context and in particular to contextual distinctions like that between the moment or place of utterances and other moments or places or that between the speaker, the hearer and others." In Chiyao, the deictic role is performed by demonstrative particles which occur before and after their heads as split demonstratives. The deictic distinctions made by demonstrative particles may be spatial (referring to physical location), temporal (referring to an event in relation to time) or emotional (referring to something in the mind).

The demonstrative particles indicate deixis in three major dimensions, proximal (closer to the speaker) (12a), non-proximal (closer to the hearer) (12b) and distal (far from both the speaker and the hearer) (12c).

$\begin{aligned} & \text { a. Achi chi-tengu } \\ & \text { DEM 7-chair }\end{aligned}$
'This chair'
$\begin{aligned} & \text { PART } \\ & \text { b. Acho chi-tengu }\end{aligned}$ cho
DEM 7-chair
'That chair'
$\begin{array}{ll}\text { C. Achila chi-tengu } & \text { chila } \\ \text { DEM 7-chair } & \text { PART } \\ \text { 'That chair (over there)' }\end{array}$

As these examples illustrate, the final element of the demonstrative particle changes in response to deixis. Thus, the final vowel is - $i$ in proximal, -0 in non-proximal, and -la in distal. It is also important to note that the utterances in the examples above may be accompanied by gestures such as pointing to specific entities intended by the speaker. Table 2 further illustrates these changes in other noun classes.

4Derived from the verb jasama 'open a mouth' 
Table 2

Chiyao demonstrative particles in relation to noun classes and spatial dimensions

\begin{tabular}{|c|c|c|c|c|c|c|c|c|c|}
\hline \multirow{2}{*}{ Class } & \multirow[b]{2}{*}{ Prefix } & \multirow[b]{2}{*}{ Example } & \multirow[b]{2}{*}{ Gloss } & \multicolumn{3}{|c|}{ demonstratives } & \multicolumn{3}{|c|}{ particles } \\
\hline & & & & PROX & $\begin{array}{l}\text { NON } \\
\text { PROX }\end{array}$ & DIST & PROX & $\begin{array}{l}\text { NON } \\
\text { PROX }\end{array}$ & DIST \\
\hline 1 & $m u-$ & mundu & person & aju & ajo & ajula & $-j u$ & $-j o$ & -jula \\
\hline 2 & va- & vandu & people & ava & avo & avala & $-v a$ & $-V O$ & -vala \\
\hline 3 & $m-$ & mteela & tree & $a w u$ & awo & awula & $-w u$ & $-w o$ & -wula \\
\hline 4 & $m i-$ & miteela & trees & $a j i$ & ajo & ajila & $-j i$ & - jo & -jila \\
\hline 5 & li- & lindanda & egg & ali & alyo & alila & -10 & $-1 y o$ & -lila \\
\hline 6 & ma- & $\begin{array}{l}\text { mandand } \\
a\end{array}$ & eggs & aga & ago & agala & $-g a$ & -90 & -gala \\
\hline 7 & chi- & chipuula & knife & achi & acho & achila & -chi & -cho & -chila \\
\hline 8 & $i-/ y-$ & ipuula & knives & ayi & ayo & ayila & $-y i$ & $-y o$ & -yila \\
\hline 9 & $n$ & ndembo & elephant & $a j i$ & ajo & ajila & $-j i$ & - jo & -jila \\
\hline 10 & $n$ & ndembo & $\begin{array}{l}\text { elephant } \\
\text { s }\end{array}$ & asi & asyo & asila & $-s i$ & -syo & -sila \\
\hline 11 & lu- & lusulo & river & alu & alo & alula & $-1 u$ & -10 & -lula \\
\hline 12 & ka- & kajuni & small bird & aka & ako & akala & $-k a$ & $-k o$ & -kala \\
\hline 13 & tu- & tujuni & $\begin{array}{l}\text { small } \\
\text { birds }\end{array}$ & atu & ato & atula & $-t u$ & -to & -tula \\
\hline 14 & $u-$ & ukana & liquor & $a u$ & awo & awula & $-w u$ & $-w o$ & -wula \\
\hline 15 & ku- & kulya & eating & $a k u$ & ako & akula & $-k u$ & $-k o$ & - -kula \\
\hline 16 & pa- & paasi & down & apa & apo & apala & $-p a$ & $-p o$ & -pala \\
\hline 17 & ku- & kumchiji & left & $a k u$ & ako & akula & $-k u$ & $-k o$ & $-k u l a$ \\
\hline 18 & $m u-$ & $\begin{array}{l}\text { mulisimb } \\
0\end{array}$ & $\begin{array}{l}\text { inside the } \\
\text { pit }\end{array}$ & $a m u$ & amo & amula & $-m u$ & $-m o$ & -mula \\
\hline
\end{tabular}

The extract in (13) below provides a contextual example of some of the demonstrative particles presented in Table 2 above.

(13) . Ní kusigála kwaúsya akalúnga avá avá, asungúla, "mmwé yéléyi mwaípatilé kwaapi?” Ni pâkuti "ngóógópa kúsáálá",... Kwaakába pêpala ni pâkuti "nné, babá nganinaulâga. Ni vaatosile au ntéélá au, aga mâlifa ga, kutí aju mûndu ju ave jwánsíma."

And they asked the hare, "where did you get these skills?" And he answered "I can't tell you." After persuading him for some time, he finally revealed, "I did not kill my father. He is the one who gave me this idea, these skills, so that this person should get healed."

Three pairs of demonstrative particles are observable in the texts in (13) above: au ... au, aga ... ga, and aju ... ju. In all these examples, the demonstrate particles indicate a spatial relationship between the speaker, the hearer and the location of the event.

\section{Emotional role}

Some particles in Chiyao function to express a speaker's emotional response to a situation or event, such as surprise, anger and shock. Syntactically, they occur at the beginning of a clause and they are separated from the rest of a sentence by an intonation break. The table below presents common emotional particles in Chiyao and the feelings they convey.

Table 3: Emotional particles and their feelings

\begin{tabular}{|l|l|}
\hline Particle & Feeling communicated \\
\hline ku! & disapproval \\
\hline ogwe! & surprise \\
\hline
\end{tabular}




\begin{tabular}{|l|l|}
\hline maawo! & pain \\
\hline ama! & shock \\
\hline cha! & surprise or shock due to unusual size, shape, behaviour, etc. \\
\hline ba! & reluctance \\
\hline che! & despise \\
\hline nyo! & anger \\
\hline
\end{tabular}

The extracts below illustrate the context of use of some of the emotional particles in Table 3 above.

(14) a. Puváiche kwiikwáta atá inyama íjáwó yátójiimé kuti áma! vé vandu vá kwâvájíla syésila mbémbe sila.

When they arrived at the party, other animals were all surprised, wow! Those horns have fitted him very well.

b. Achínyama achínjao kuti áma! ányaámwe, jwéléjo mbóná yélêyí?.

His fellow animals were all surprised, "gosh! what's happening to him?".

These two extracts are from a traditional story in which there was a party to be attended by animals with horns. The hyena decided to make wooden horns in order to attend the party. The horns fitted him very well to the extent that even other animals were surprised to see an animal with such beautiful horns. As seen in line 1 of extract (14a), the particle áma! has been used to express the way these other animals were surprised at the hyena's appearance.

As the plot of the story unfolds, it is shown in extract (14b) that as the sun shone, the hyena's horns fell (because the glue he had used to fix them melted). This event again surprises other animals as expressed by the particle áma! in extract (14b).

More examples of emotional particles are illustrated in (15-18) below.

Ku! ana mmwe mkwete lunda?

PART PART you have brain

'Are you really of sound mind?'

(16) Ogwe! tabiya jachi jelejo!

PART behaviour what that

'What sort of behaviour is that!'

(17) Cha! i-latu naambo!

PART 8-shoes but

'Oh my gosh, what strange shoes!'

(18) Ba! kundenda nne li-velu?

PART INF-make me 5-stupid

'Do you consider me stupid?'

In examples (15-18) above, some particles presented in Table 3 above are put in sentential context. The particle $\boldsymbol{k} \boldsymbol{u}$ in (15) expresses the speaker's feeling of disapproval of an act or behaviour of the addressee. It therefore expresses a negative feeling. And so is the particle Ogwe in (16). In example (17) the particle cha is used by the speaker to express his/her surprise over the shoes probably due to their strange or funny looking. The particle ba in (18) indicates the speaker's realisation that someone was going to do something unpleasant to him and thus the speaker is reluctant to offer any further cooperation. 


\section{Additive role}

Additive particles are used to add information to the already provided information. The already provided information may just be implied, that is, it may not be overtly expressed in the same sentence but it is recoverable in context by the addressee. Three additive particles are operational in Chiyao: ambano 'now (that)', noombe 'also/too/as well', and $n i$ 'and/so'. The examples below are illustrative.

(19) Ní vátite ambáno pélépa tusose lîpula lyá kúkándichila gé mavéngwa go. Ní vasósile lîpula ní vapátile, ní kwaakándichilaga ambusánga vao.

So they said now we have to find some glue for fixing these horns. So he looked for some glue and he got it, and he fixed the horns on his friend's head.

(20) Asungúla, kwá Chíyáo akúvílánjikwa akalúnga, babá vao nganivaulága. Váájile kwaasísa pâmbúgu ní kuujágá kumusi. Achínjáó kulólá kuti bilá sháka nombe vévala, vaauléje.

The hare did not kill his father. He just went to hide him in a cave and came back home. When his fellows saw him, they believed that he too had killed his father.

Texts (19) and (20) have both been extracted from the same story, the story of the hyena that fitted himself with fake horns in order to attend a party which was meant for animals with horns only. Text (19) begins with an additive particle ni which roughly translates into English 'so'/'therefore' since it is the result of a preceding (covert) discussion between the two dominant characters in the story, the hyena and the hare. The same text (line 1) makes use of the additive particle ambáno which signals addition of information as a solution to the existing challenge that the two characters in the story are facing. The additive particle ni 'and/so' again opens the second sentence of line 1 in the sense of the English subordinate conjunction 'so', but appears again in line 2 of the same text in the contexts equivalent to the English conjunction 'and'. It appears that the additive particle ní triggers slightly different semantic interpretations depending on its placement in the sentence. When it occurs sentence initially, it introduces a result or a conclusion of some preceding events, and when it occurs in a compound sentence, it introduces more events performed by the same subject. On the other hand, the additive particle ambáno introduces a solution.

The additive particle nombe in line 2 of text (19) has an adverbial reading equivalent to the English adverb 'also/too/as well'. It also indicates addition.

Additive particles have also been studied in Kinande where they have been observed to exist in two types, namely na and naye, each occurring in a different syntactic slot (Schneider-Zioga, 2015). While na precedes the noun it occurs with, naye follows the noun, as shown in the examples below.
(21) a. [na Kambale]
mwahikere
and 1 Kambale
Aff.1.arrived

'Also KAMBALE arrived.'

b. [Kambale] [na-ye] mwahikere

1 Kambale and-3s Aff.1.arrived

'KAMBALE, too, arrived.'

(Kinande, Schneider-Zioga, 2015:254) 


\section{Contrast role}

Contrast particles perform the functions equivalent to the English contrast conjunctions 'but', 'however', and 'although'. The findings establish that there is only one contrast particle in Chiyao, the particle nambo 'but/however/although.' This particle occurs clause initially, as illustrated in (22) below.

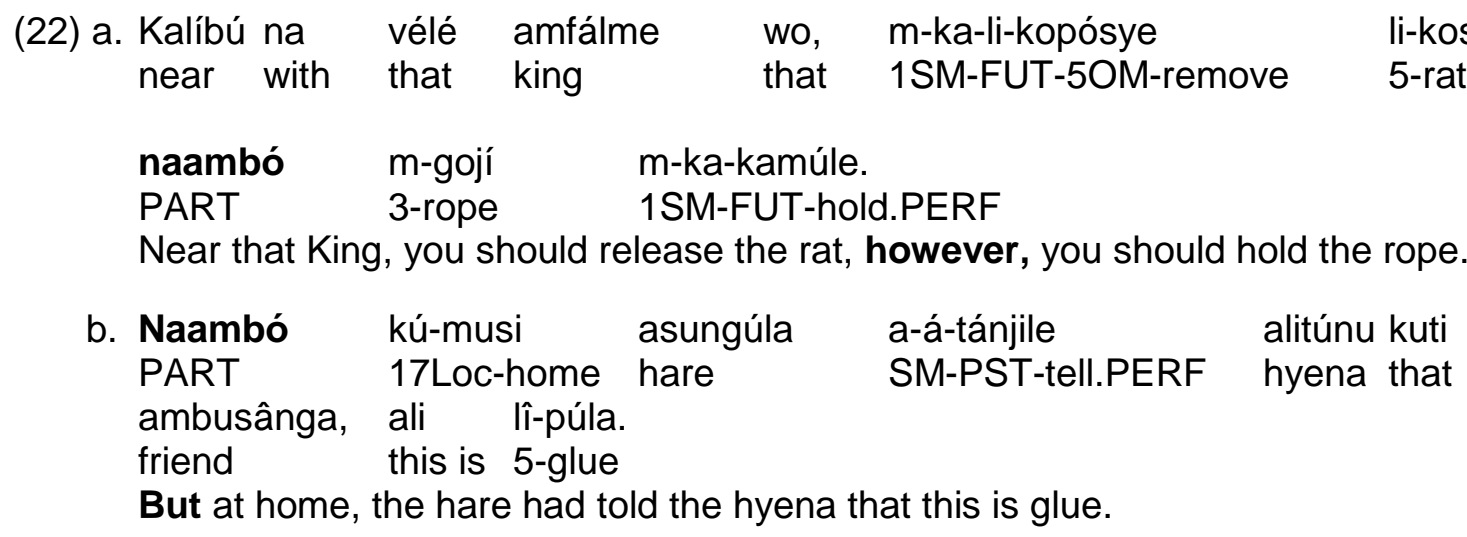

The texts in (22) are extracted from a traditional story in which animals agreed to kill all their elder siblings so that they (young animals) could live freely. The hare, who happened to be so clever, did not kill his father. When the young king who was appointed from among the young animals after all elders had been killed falls sick, it is the hare's father who offers medication for the king. The text in (22a) captures some prescriptions that the hare's father tells his son what to do to rescue the king. The particle naambó has been used to contrast the information said in the second part of the sentence from the first part. Similarly, in (22b) naambó has been used to introduce information that contrasts with the implied preceding information.

\section{Summary and Conclusion}

The foregoing analysis has established three major issues in relation to particles in Chiyao, namely the environment of occurrence, scope of interpretation, and communicative role. Regarding the occurrence, the analysis has indicated that particles in Chiyao can occur in three major types of environment: within the NP (e.g. interrogative particles, demonstrative particles, and exclusion particles), within the VP (e.g. interrogative particles, exclusion particles, and negative particles), and in pre-sentential position (e.g. emotional particles, additive particles, and contrast particles). Concerning the scope of interpretation, the analysis has established that particles that occur within the NP have their scope of interpretation limited to the NP while those that occur as part of the VP have their meaning apply to the entire sentence. This is because a verb is the basic unit of a sentence. As for the communicative role, it has been shown that the Chiyao particles performs a number of significant roles, including emphatic roles, such as emphasising negation; and exclusive roles, that is, to single out some elements within a clause from the rest of a clause in order to show focus. The analysis has further indicated that particles are also used to signal interrogation - warning the hearer that what follows is a question, and for anaphoric purposes whereby the speaker maintains the addressee's attention by referring him/her back to the earlier mentioned entity/subject. Moreover, particles in Chiyao indicate deixis as well as emotions such as surprise, anger, disapproval and shock. Finally, particles indicate contrast and addition, with the added information either being resulting or conclusive. Table 4 summarizes the environment of occurrence, scope of interpretation, and communicative role of particles in Chiyao. 
Table 4

Environment of occurrence, scope of interpretation and communicative role of particles in Chiyao

\begin{tabular}{|c|c|c|c|c|}
\hline & Type of particle & $\begin{array}{l}\text { Environment of } \\
\text { occurrence }\end{array}$ & $\begin{array}{l}\text { Scope of } \\
\text { interpretation }\end{array}$ & Communicative role \\
\hline 1 & $\begin{array}{l}\text { Interrogative } \\
\text { particles }\end{array}$ & NP; VP & Sentence & $\begin{array}{ll}\text { - } & \text { Attention calling } \\
\text { - } & \text { Introducing a question }\end{array}$ \\
\hline 2 & $\begin{array}{l}\text { Exclusive } \\
\text { particles }\end{array}$ & NP; VP & NP; VP & $\begin{array}{l}\text { - To single out some } \\
\text { elements of a clause }\end{array}$ \\
\hline 3 & $\begin{array}{l}\text { Negative } \\
\text { particles }\end{array}$ & VP & Sentence & $\begin{array}{l}\text { Emphasising } \\
\text { negation }\end{array}$ \\
\hline 4 & Locative particles & NP & NP & - Anaphoric reference \\
\hline 5 & $\begin{array}{l}\text { Demonstrative } \\
\text { particles }\end{array}$ & NP & NP & - Deictic reference \\
\hline 6 & Emotional & Pre-sentential & Sentence & $\begin{array}{ll}\text { Evoke } & \text { speaker's } \\
& \text { feelings }\end{array}$ \\
\hline 7 & Additive particle & Pre-sentential & Sentence & $\begin{array}{ll} & \text { Addition } \\
\text { information }\end{array}$ \\
\hline 8 & Contrast particles & Pre-sentential & Sentence & - $\quad$ Marking contrast \\
\hline
\end{tabular}

\section{References}

Beeching, K. (2016). Pragmatic markers: Meaning in social interaction. Cambridge: Cambridge University Press.

Bonifazi, A., Annemieke, D., \& de Kreij, M. (2016). Particles in Ancient Greek discourse: Exploring particle use across genres. Hellenic Studies series 79. Washington, DC: Centre for Hellenic Studies.

Christidis, A. (1990). On the categorial status of particles: The case for 'holophrasis'. Lingua, $82,53-82$.

Crible, L. (2018). Discourse markers and (dis)fluency. Amsterdam: John Benjamins.

Crystal, D. (1998). A dictionary of linguistics and phonetics ( $6^{\text {th }}$ ed.). Oxford: Blackwell Publishing.

Devos, M., \& Van der Auwera, J. (2013). Jespersen cycles in Bantu: Double and triple negation. Journal of African Languages and Linguistics, 34(2), 205-274.

Fominyam, H., \& Simik, R. (2017). The morphosyntax of exhaustive focus: A view from Awing (Grassfields Bantu). Natural Language and Linguistic Theory, 35, 1027-1077.

Halliday, M.A.K., \& R. Hasan. (1976). Cohesion in English. London: Longman Group Limited.

Krifka, M. (1998). Additive particles under stress. In D. Strolovitch \& A. Lawson (Eds.), Proceedings of SALT VIII (pp. 111-128). New York: Cornell University.

Kusevska, M. (2019). Research on pragmatic markers: Domains and approaches. Journal of Contemporary Philology, 2(1), 7-23.

Müller, S. (2005). Discourse markers in native and non-native English discourse. Amsterdam/ Philadelphia: John Benjamins.

Ngonyani, D. (2013). Surrogate imperatives in Bantu languages with postverbal negative particles. In O. O. Orie, \& K. W. Sanders (Eds.), Selected proceedings of the 43rd annual conference on African linguistics (pp. 177-187). Somerville, MA: Cascadilla Proceedings Project.

Nicolle, S. (2000). Markers of general interpretive use in Amharic and Swahili. In G. Andersen \& T. Fretheim (Eds.), Pragmatic markers and propositional attitude (pp. 173-188). Amsterdam: John Benjamins.

Roussou, A., \& Tsangalidis, A. (2010). Reconsidering the modal particles in Modern 
Greek. Journal of Greek Linguistics, 10, 45-75.

Schiffrin, D. (1987). Discourse markers. Cambridge: Cambridge University Press.

Schneider-Zioga, P. (2015). Additive focus in Kinande. In R. Kramer (Eds.), Selected proceedings of the 44th annual conference on African linguistics, 254-263. Somerville, MA: Cascadilla Proceedings Project.

Tzartzanos, A. (1946). Modern Greek syntax (of the common demotic language). Thessaloniki: Kyriakidis.

Van der Wal, J. (2014). Topic and focus in Bantu comparative syntax: 3 steps towards minimalist features. $47^{\text {th }}$ Meeting of the Societas Linguistica Europaea, 11-14.

Van de Velde, M. (2013). The Bantu connective construction: In A. Carlier, \& J. Verstraete (Eds.), The genitive [case and grammatical relations across languages] (pp. 217-252). Amsterdam: John Benjamins.

Zwicky, A. (1985). Clitics and particles. Languages, 61, 283-305. 